National Water Quality Program

National Water-Quality Assessment Project

\title{
Groundwater Quality in the Colorado Plateaus Aquifers, Western United States
}

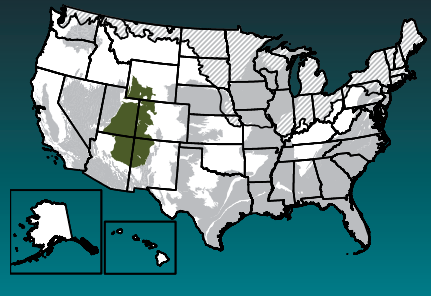

Groundwater provides nearly 50 percent of the Nation's drinking water. To help protect this vital resource, the U.S. Geological Survey (USGS) National Water-Quality Assessment (NAWQA) Project assesses groundwater quality in aquifers that are important sources of drinking water. The Colorado Plateaus aquifers constitute one of the important areas being evaluated.

\section{Background}

The Colorado Plateaus aquifers underly an area of about 141,000 square miles in southwestern Wyoming, eastern Utah, western Colorado, northwestern New Mexico, and northeastern Arizona. Groundwater is the primary source of drinking water for many of the 1.2 million people living in the region that overlies the aquifer. The extent of the Colorado Plateaus aquifers is based on the U.S. Geological Survey (2003) map of principal aquifers. The aquifers rank 28th in the Nation as a source of groundwater for public supply, with about 102 million gallons per day pumped for this use in 2000; the aquifers are also used for agricultural irrigation, with about 81.9 million gallons per day pumped for this use in 2000 (Maupin and Barber, 2005; Kingsbury and others, 2021). Land use overlying the aquifers is composed primarily of natural land cover (97 percent) with relatively small areas of pasture and agricultural land (1.9 percent) and urban and other developed land (1 percent; Homer and others, 2015). Major urban areas overlying the aquifer are Flagstaff, Arizona (total metropolitan area population of about 134,000), and Grand Junction, Colorado (total metropolitan area population of about 147,000; U.S. Census Bureau, 2010).

The Colorado Plateaus aquifers are four stratigraphically distinct regional aquifers: the Uinta-Animas, Mesaverde, Dakota-Glen Canyon, and Coconino-De Chelly aquifers, which are Tertiary to Permian age rocks (Davidson, 1979; Robson and Banta, 1995; Glover and others, 1998). The regional aquifers are made up of several local aquifers in different formations, primarily sandstones and conglomerates (some are massive), siltstone, carbonate rocks, and shale layers with varying degrees of lithification. Fractures, faults, and solution cavities in carbonate rocks locally increase transmissivity. The sedimentary rocks making up the Colorado Plateaus aquifers are thousands of feet thick, offset by faults, and variably uplifted or subsided. The geologic structure and topography (mountains and deeply incised canyons) add to the complexity of the aquifers. The climate of the region is arid to semiarid at lower elevations and cool and wet at higher elevations in mountainous terrain to the east and north (Robson and Banta, 1995).

Groundwater quality in the Colorado Plateaus aquifers was evaluated in 2017 by sampling 60 publicsupply wells. Sampling sites were spatially distributed across the extent of the aquifers: Arizona (15 wells), New Mexico (10 wells), Utah (19 wells), Colorado (11 wells), and Wyoming (5 wells). Parts of the region are sparsely populated, and public-supply wells are not evenly distributed. Consequently, the study area was delineated by placing 20 -kilometer (12.4-mile) buffers around existing publicsupply wells; an equal-area grid was then defined within the buffered area. For this discussion, we define the study area as the depth zone used for public supply in the Colorado Plateaus aquifers in the buffered area (however, two sample sites within the mapped boundaries of geologic units that constitute the aquifers were located outside the extent of the buffered area based on availability of wells for sampling). Wells were completed at depths from 100 to 3,636 feet with a median of 565 feet, and open intervals were 10 to about 1,790 feet. Water-quality data collected from the spatially distributed wells are representative of water quality in the study area, following the approach described by Belitz and others (2010). This approach allows for the estimation of the percentage of the study area with concentrations that are high, moderate, and low with respect to constituent benchmarks. The accuracy of the estimates depends on the distribution and number of wells, not the size of the area (Belitz and others, 2010). Samples were analyzed for a large number of waterquality constituents derived from natural and human sources.

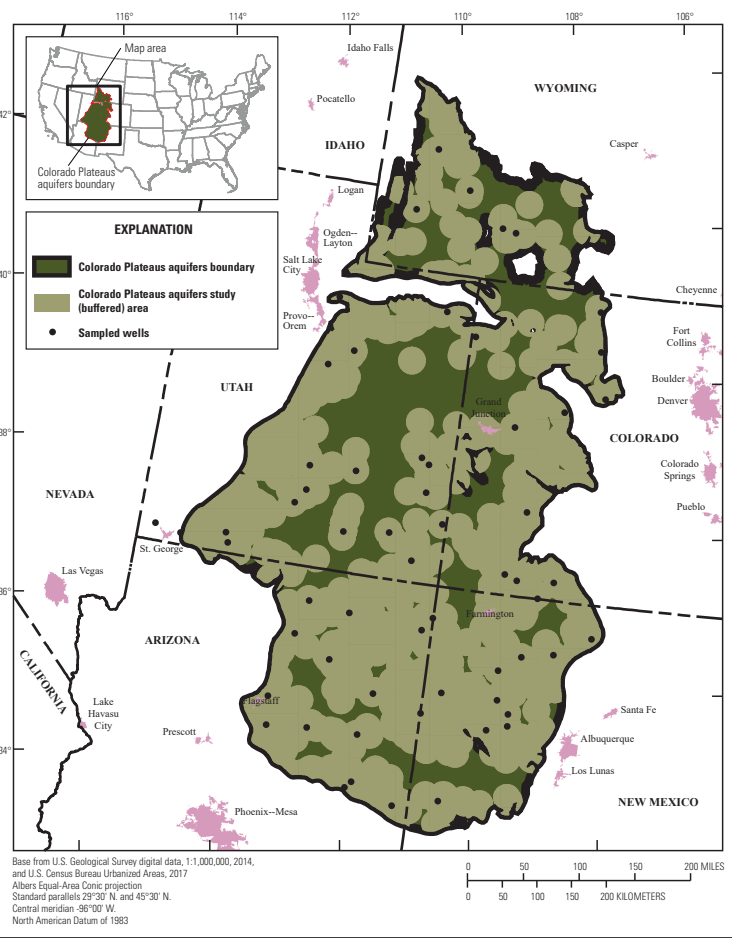

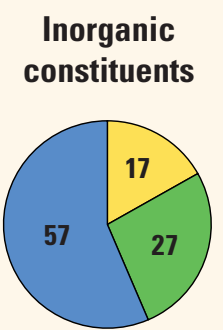

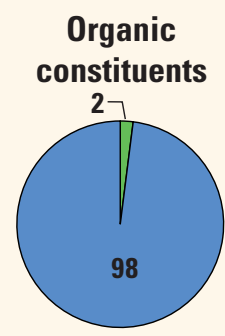

\section{CONSTITUENT CONCENTRATIONS}

$\bigcirc$ High $\bigcirc$ Moderate $\bigcirc$ Low or not detected

Values are a percentage of the study area with concentrations in the three specified categories. Percentages might not sum to 100 because of rounding.

Principal Aquifer Studies (Burow and Belitz, 2014) are designed to evaluate groundwater used for public supply prior to any treatment. Groundwater quality is assessed by comparing concentrations to benchmarks established for drinkingwater quality. Benchmarks and definitions of high, moderate, and low relative concentrations are discussed at the bottom of page 3. Water from 84 percent of the study area did not have high concentrations of any contaminant measured.

Many inorganic constituents are naturally present in groundwater. The concentrations of inorganic constituents can be affected by natural processes as well as by human activities. One or more inorganic constituents with human-health benchmarks were detected at high concentrations in about 17 percent of the study area and at moderate concentrations in about 27 percent.

Organic constituents derived from human activities are used in household, business, industrial, and agricultural products. They can enter the environment through normal usage, spills, or improper disposal. Organic constituents with human-health benchmarks were detected at moderate concentrations in about 2 percent of the study area. 


\section{Results: Groundwater Quality at the Depth Zone Used for Public Supply in the Colorado Plateaus Aquifers}

\section{INORGANIC CONSTITUENTS}

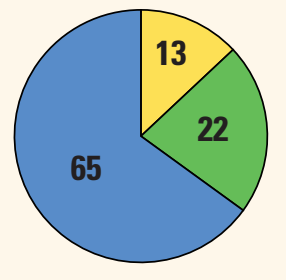

\section{Trace \\ elements and major and minor ions}

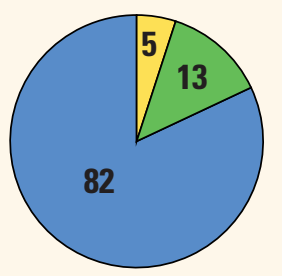

\section{Radioactive constituents}
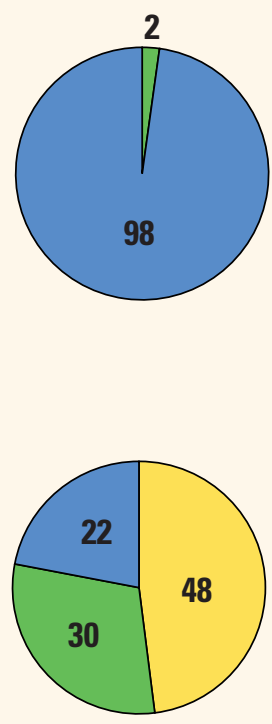

Constituents with non-health benchmarks

\section{Inorganic Constituents With Human-Health Benchmarks}

Trace elements and major and minor ions are naturally present in the minerals of rocks, soils and sediments, and in the water that comes into contact with those materials. Samples were analyzed for 34 trace elements and major and minor ions, of which 22 have human-health benchmarks (health-based screening level [HBSL] benchmarks were updated in 2018 to include aluminum, cobalt, and iron; Norman and others, 2018). Constituents from this group were detected at high concentrations in about 13 percent of the study area (the depth zone used for public supply) and at moderate concentrations in about 22 percent. Arsenic was the most commonly detected trace element at high ( 8 percent) and moderate (14 percent) concentrations. Manganese was also detected at high ( 3 percent) and moderate ( 3 percent) concentrations in the study area, and cobalt had high concentrations in 2 percent of the study area. Fluoride, iron, uranium, molybdenum, and strontium were detected at moderate concentrations in 2 to 7 percent of the study area.

Radioactivity is the release of energy or energetic particles during the spontaneous decay of unstable atoms. Humans are continuously exposed to small amounts of natural radioactivity. Most of the radioactivity in groundwater comes from the decay of isotopes of uranium and thorium that are naturally present in minerals in aquifer materials. Samples were analyzed for eight radioactive constituents, of which four have human-health benchmarks. Radioactive constituents were detected at high levels in about 5 percent of the study area and at moderate levels in about 13 percent of the study area. Gross-alpha activity and radium were the only radioactive constituents detected at high concentrations.

Nutrients are naturally present at low concentrations in groundwater; high and moderate concentrations (relative to human-health benchmarks) generally result from human activities. Samples were analyzed for five nutrients, of which two (nitrate and nitrite) have human-health benchmarks. Common sources of nutrients, aside from soils, include fertilizer applied to crops and landscaping, seepage from septic systems, and human and animal waste. Nitrate was not measured at high concentrations; it occurred at moderate concentrations in about 2 percent of the study area.

\section{Inorganic Constituents and Field Measurements With Non-Health-Based Benchmarks}

(Not included in water-quality overview charts shown on the front page)

Some constituents affect the aesthetic properties of water, such as taste, color, and odor, or can create nuisance problems, such as staining and scaling. The benchmarks used for these constituents were non-regulatory secondary maximum contaminant level (SMCL) benchmarks established for public drinking water. Some constituents, such as manganese and fluoride, have human-health benchmarks and SMCLs. Samples were analyzed for 11 constituents that have SMCLs. One or more of these were present at high concentrations or values relative to the SMCL in about 48 percent of the study area and at moderate concentrations in about 30 percent.

Total dissolved solids (TDS) concentration is a measure of the salinity of the groundwater based primarily on concentrations of ions. All water naturally contains TDS because of the weathering and dissolution of minerals in rocks and sediments. Concentrations of TDS can be high because of natural factors or as a result of human activities such as applications of road salt, fertilizers, or other chemicals to the land surface in urban or agricultural areas. Most of the study area had high (37 percent) or moderate (35 percent) concentrations of TDS relative to the SMCL. Sulfate, fluoride, and chloride were similarly measured at high concentrations relative to the SMCL in about 17,5 , and 2 percent of the study area, respectively, and at moderate concentrations in about 12,7 , and 7 percent, respectively.

Anoxic conditions in groundwater (low amounts of dissolved oxygen) can result in the release of iron and manganese in minerals to the groundwater. Manganese was present at high concentrations relative to the SMCL in about 13 percent of the study area and at moderate concentrations in 7 percent. Iron was present at high concentrations relative to the SMCL in about 17 percent of the study area and at moderate concentrations in 7 percent.

Groundwater $\mathrm{pH}$ has an SMCL range of 6.5 to 8.5. In about 2 percent of the study area, the $\mathrm{pH}$ was less than 6.5 , which is acidic and potentially corrosive; in about 22 percent of the study area, the $\mathrm{pH}$ was greater than 8.5 , or alkaline. 


\section{Results: Groundwater Quality at the Depth Zone Used for Public Supply in the Colorado Plateaus Aquifers}

\section{ORGANIC CONSTITUENTS}

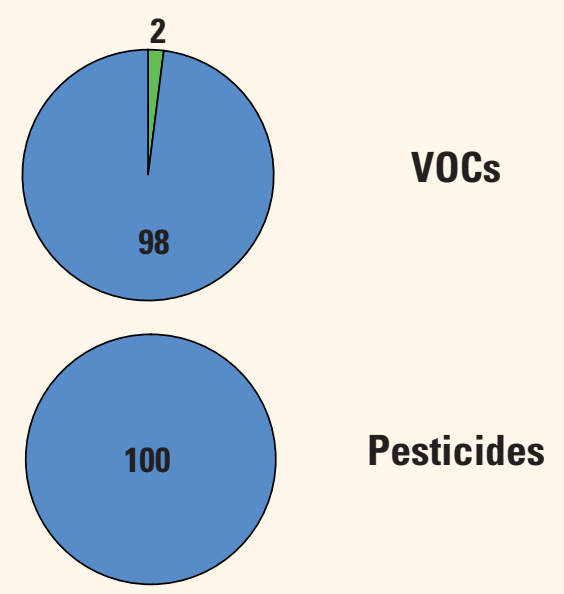

\section{Volatile Organic Compounds With Human-Health Benchmarks}

Volatile organic compounds (VOCs) are present in many household, commercial, industrial, and agricultural products and are characterized by their tendency to volatilize (evaporate). Samples were analyzed for 85 VOCs, of which 51 have human-health benchmarks. VOCs were detected at moderate concentrations in 2 percent of the study area (based on carbon tetrachloride, dichloromethane, and chloroform concentrations).

\section{Pesticides With Human-Health Benchmarks}

Pesticides, including herbicides, insecticides, and fungicides, are applied to crops, gardens and lawns, around buildings, and along roads to help control unwanted vegetation (weeds), insects, fungi, and other pests. Samples were analyzed for 225 pesticide compounds (pesticides and their breakdown products), of which 119 have human-health benchmarks. Pesticide compounds were not detected at high or moderate concentrations in the study area.

\section{BENCHMARKS FOR EVALUATING GROUNDWATER QUALITY}

The USGS NAWQA Project uses benchmarks established for drinking water to provide context for evaluating the quality of untreated groundwater. The quality of water received by consumers can be different from results presented herein because after withdrawal, groundwater from an individual well may be treated or blended with water from other sources prior to delivery. Federal regulatory benchmarks for protecting human health are used for this evaluation of water quality when available. Otherwise, non-regulatory human-health benchmarks and non-regulatory aesthetic benchmarks are used. Some constituents analyzed do not have benchmarks and, thus, are not considered in this context. Human-health benchmarks are available for 28 of 55 inorganic constituents and properties and 170 of 310 organic constituents.

Concentrations are considered high if they are greater than a human-health benchmark (Norman and others, 2018) or SMCL. For inorganic constituents, concentrations are moderate if they are greater than one-half of a benchmark. For organic constituents, concentrations are moderate if they are greater than one-tenth of a benchmark; this lower threshold is used because organic constituents are generally less prevalent and have smaller concentrations relative to benchmarks than inorganic constituents (Toccalino and others, 2004).

\section{Benchmark Type and Value for Selected Constituents}

This table presents benchmarks for those constituents detected at high concentrations in the Colorado Plateaus aquifers. Benchmark types are regulatory U.S. Environmental Protection Agency (EPA) maximum contaminant levels (MCLs; U.S. Environmental Protection Agency, 2020a), non-regulatory health-based screening levels (HBSLs; Norman and others, 2018), and non-regulatory EPA secondary maximum contaminant levels (SMCLs; U.S. Environmental Protection Agency, 2020b).

$[\mu \mathrm{g} / \mathrm{L}$, microgram per liter (or part per billion); mg/L, milligram per liter (or part per million); $\mathrm{pCi} / \mathrm{L}$, picocurie per liter]

\begin{tabular}{|c|c|c|c|c|c|}
\hline \multirow{2}{*}{ Constituent } & \multicolumn{2}{|c|}{ Benchmark } & \multirow{2}{*}{ Constituent } & \multicolumn{2}{|c|}{ Benchmark } \\
\hline & Type & Value & & Type & Value \\
\hline Arsenic & MCL & $10 \mu \mathrm{g} / \mathrm{L}$ & Total dissolved Solids (TDS) & SMCL & $500 \mathrm{mg} / \mathrm{L}$ \\
\hline Gross-alpha activity & MCL & $15 \mathrm{pCi} / \mathrm{L}$ & Sulfate & SMCL & $250 \mathrm{mg} / \mathrm{L}$ \\
\hline Radium $226+228$ & MCL & $5 \mathrm{pCi} / \mathrm{L}$ & Chloride & SMCL & $250 \mathrm{mg} / \mathrm{L}$ \\
\hline Cobalt & HBSL & $2 \mu \mathrm{g} / \mathrm{L}$ & Fluoride & SMCL & $2 \mathrm{mg} / \mathrm{L}$ \\
\hline Manganese & HBSL & $300 \mu \mathrm{g} / \mathrm{L}$ & Iron & SMCL & $300 \mu \mathrm{g} / \mathrm{L}$ \\
\hline Manganese & SMCL & $50 \mu \mathrm{g} / \mathrm{L}$ & $\mathrm{pH}$ & SMCL & $6.5-8.5$ \\
\hline
\end{tabular}




\section{Spatial Distribution of Constituent Concentrations Above Human-Health Benchmarks}

\author{
Inorganic constituents with \\ human-health benchmarks were \\ measured at high and moderate \\ concentrations in about 43 percent \\ of the Colorado Plateaus aquifers. \\ The most prevalent of these \\ constituents were arsenic, gross- \\ alpha radioactivity, manganese, \\ and combined radium (Ra-226 \\ plus Ra-228). Previous studies in \\ the Colorado Plateaus aquifers \\ have also found elevated arsenic \\ concentrations (Welch and \\ others, 1988; Dam, 1995). The \\ distribution of moderate and high \\ concentrations of arsenic and \\ manganese occurred primarily in \\ the southern half of the Colorado \\ Plateaus aquifers, in southern \\ Utah and northern Arizona and \\ New Mexico, whereas elevated \\ concentrations of radioactive \\ constituents occurred throughout \\ the aquifer. These different \\ spatial patterns in water quality \\ might reflect a number of \\ factors, such as differences in \\ the composition of aquifer rocks, \\ aquifer flow-path characteristics, \\ aquifer geochemical conditions, \\ groundwater age distributions, \\ and climate.
}

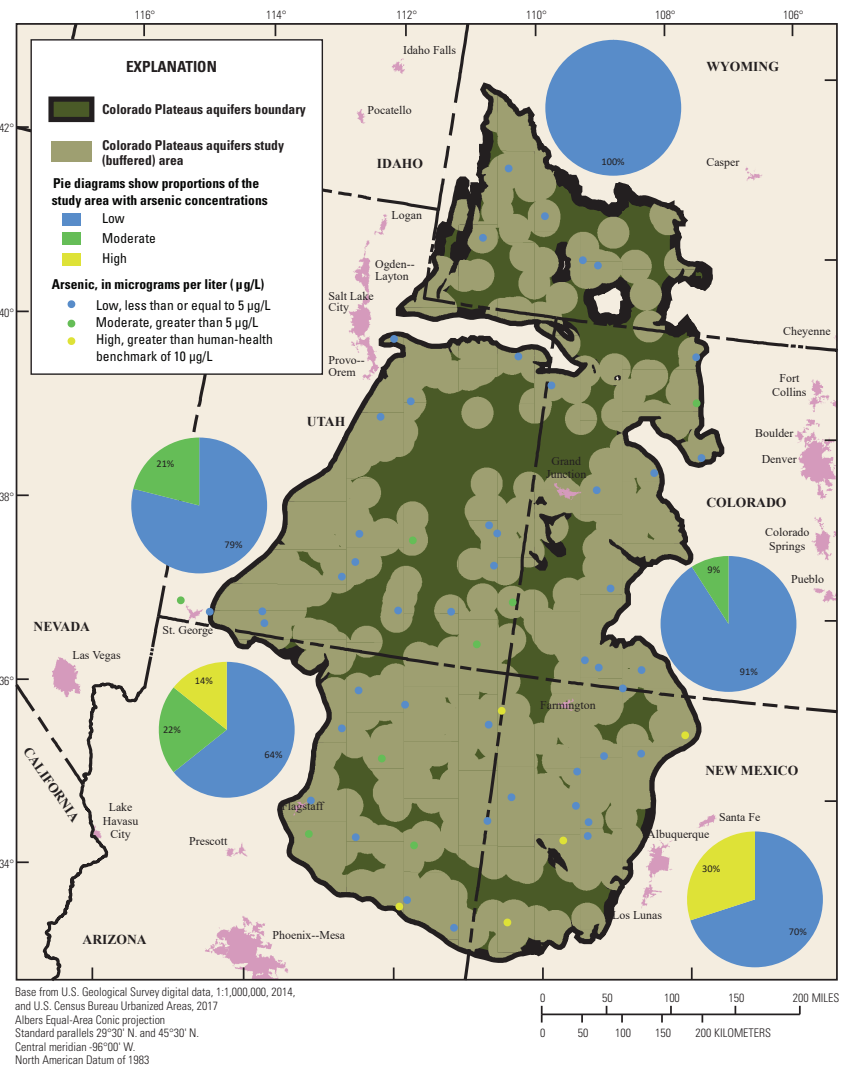

By James Degnan and MaryLynn Musgrove

\section{REFERENCES CITED}

Belitz, K., Jurgens, B., Landon, M.K., Fram, M.S., and Johnson, T., 2010, Estimation of aquifer scale proportion using equal area grids-Assessment of regional scale groundwater quality: Water Resources Research., v. 46, 14 p., https://doi.org/10.1029/2010WR009321.

Burow, K.R., and Belitz, K., 2014, Groundwater studies—Principal aquifer surveys: U.S. Geological Survey Fact Sheet 2014-3024, 2 p., https://doi.org/10.3133/fs20143024.

Davidson, E.S., 1979, Summary appraisals of the Nation's ground-water resources; Lower Colorado region: U.S. Geological Survey Professional Paper 813-R, 23 p., 3 pl., https://doi.org/10.3133/pp813R.

Dam, W.L., 1995, Geochemistry of ground water in the Gallup, Dakota, and Morrison aquifers, San Juan Basin, New Mexico: Water Resources Investigations Report 94 4253, 76 p., https://doi.org/10.3133/wri944253.

Glover, K.C., Naftz, D.L., and Martin, L.J., 1998, Geohydrology of Tertiary rocks in the upper Colorado River basin in Colorado, Utah, and Wyoming, excluding the San Juan basin: U.S. Geological Survey Water-Resources Investigations Report 96-4105, 103 p., 1 pl., https://doi.org/10.3133/wri964105.

Homer, C.G., Dewitz, J.A., Yang, L., Jin, S., Daniel`son, P., Xian, G., Coulston, J., Herold, N.D., Wickham, J.D., and Megown, K., 2015, Completion of the 2011 National Land Cover Database for the contermi-nous United States-Representing a decade of land cover change information: Photogrammetric Engineering and Remote Sensing, v. 81, no. 5, p. 345-354, https://pubs.er.usgs.gov/publication/70146301.

Kingsbury, J.A., Bexfield, L.M., Arnold, T., Musgrove, M., Erickson, M.L., Degnan, J.R., Tesoriero, A.J., Lindsey, B.D., and Belitz, K., 2021, Groundwater-quality and select quality-control data from the National Water-Quality Assessment Project, January 2017 through December 2019 U.S. Geological Survey Data Series 1136, 97 p., https://doi.org/10.3133/ds1136.

Kingsbury, J.A., Sharpe, J.B., Bexfield, L.M., Arnold, T.L., Musgrove, M., Erickson, M.L., Degnan, J.R., Tesoriero, A.J., Lindsey, B.D., and Belitz, K., 2020, Datasets of groundwater-quality and select quality-control data from the National Water-Quality Assessment Project, January 2017 through December 2019 (ver. 1.1, January 2021): U.S. Geological Survey data release, https://doi.org/10.5066/P9XATXV1.

Maupin, M.A., and Barber, N.L., 2005, Estimated withdrawals from principal aquifers in the United States, 2000: U.S. Geological Survey Circular 1279, 46 p., https://doi.org/10.3133/cir1279.

Norman, J.E., Toccalino, P.L., Morman, S.A., 2018, Health-based screening levels for evaluating water-quality data (2d ed.): U.S. Geological Survey National Water-Quality Assessment Program web page, https://doi.org/10.5066/F71C1TWP.

Robson, S.G., and Banta, E.R., 1995, Ground Water Atlas of the United States: Segment 2, Arizona, Colorado, New Mexico, Utah: U.S. Geological Survey Hydrologic Atlas 730-C, p. C1-C32, https://doi.org/10.3133/ha730C

Rosecrans, C.Z., and Musgrove, M., 2020, Water Quality of groundwater used for public supply in principal aquifers of the western United States: U.S. Geological Survey Scientific Investigations Report 2020-5078, 142 p., https://oi.org/10.3133/sir20205078.

Toccalino, P.L., Norman, J.E., Phillips, R.H., Kauffman, L.J., Stackelberg, P.E., Nowell, L.H., Krietzman, S.J., and Post, G.B., 2004, Application of health-based screening levels to ground-water quality data in a state-scale pilot effort: U.S. Geological Survey Scientific Investigations Report 2004-5174, 64 p., https://doi.org/10.3133/sir20045174.

U.S. Bureau of the Census, 2010, Census of population and housing, 2010: U.S. Bureau of the Census, digital data, accessed March 1, 2018, at https://www.census.gov/prod/www/decennial.html.

U.S. Environmental Protection Agency, 2020a, National primary drinking water regulations: U.S. Environmental Protection Agency web page, accessed March 2020 at https://www.epa.gov/ground-water-and-drinking-water/national-primary-drinking-water-regulations.

U.S. Environmental Protection Agency, 2020b, Secondary drinking water standards - Guidance for nuisance chemicals: U.S. Environmental Protection Agency web page, accessed March 2020 at https://www.epa.gov/sdwa/secondary-drinking-water-standards-guidance-nuisance-chemicals.

U.S. Geological Survey, 2003, Principal aquifers of the 48 conterminous United States, Hawaii, Puerto Rico, and the U.S. Virgin Islands: U.S. Geological Survey, accessed January 4, 2016, at http://water.usgs.gov/GIS/metadata/usgswrd/XML/aquifers_us.xml.

Welch, A.H., Lico, M.S., and Hughes, J.L., 1988, Arsenic in ground water of the western United States: Groundwater, v. 26, no. 3, p. 333-347, https://doi.org/10.1111/j.1745-6584.1988.tb00397.x.

\section{Principal Aquifer Studies}

The USGS NAWQA Project

has been assessing the quality of groundwater since 1991. The NAWQA studies include Land Use Studies (LUS), Major Aquifer Studies (MAS), and Principal Aquifer Studies (PAS). These three study types are based on sampling networks of wells distributed across an area of interest. The LUS networks typically consist of observation wells that are relatively shallow, MAS networks typically consist of domestic-supply wells that are intermediate in depth, and PAS networks typically consist of public-supply wells that are relatively deep. A synthesis of deep (depth used for public supplies) groundwater quality for the western United States was reported by Rosecrans and Musgrove (2020). A regional synthesis of aquifer properties and water quality, including the Colorado Plateaus aquifers, was reported by Robson and Banta (1995). This fact sheet provides a summary of PAS data for 60 public-supply wells sampled in 2017 that represent the Colorado Plateaus aquifers (data available in Kingsbury and others, 2020).

The PAS assessments like this one allow for the comparison of constituent concentrations in untreated groundwater with benchmarks established for the protection of human health and for aesthetic qualities of drinking water. They also provide a basis for comparison of groundwater quality among the principal aquifers.

The data collected by the NAWQA Project include chemical analyses generally not available as part of regulatory compliance monitoring, including measurements at concentrations much lower than the levels used as human-health benchmarks and measurement of constituents that can be used to trace the sources and movement of groundwater.

\section{For more information}

Technical reports and hydrologic data collected for the USGS NAWQA Project may be obtained from

\section{Program Coordinator}

U.S. Geological Survey

Water Availability and Use Science Program

Email: wausp-info@usgs.gov WEB: https://water.usgs.gov/nawqa/ 